
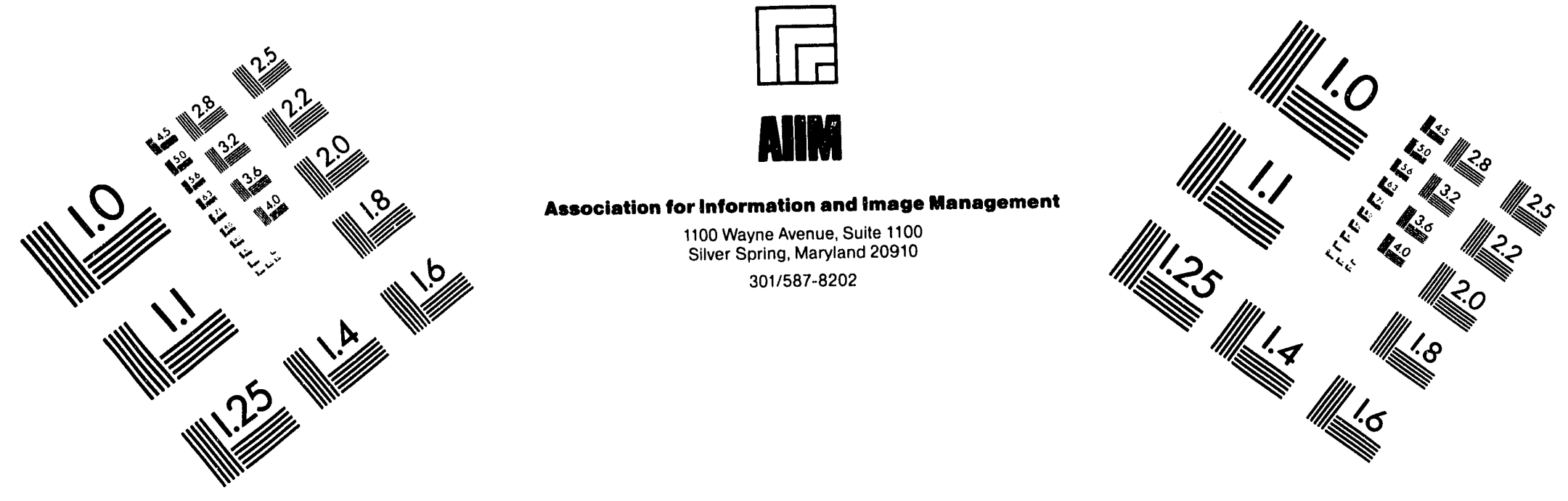

\title{
Centimeter
}

$\begin{array}{llllllllllllllll}1 & 2 & 3 & 4 & 5 & 6 & 7 & 8 & 9 & 10 & 11 & 12 & 13 & 14 & 15 & 15 m\end{array}$

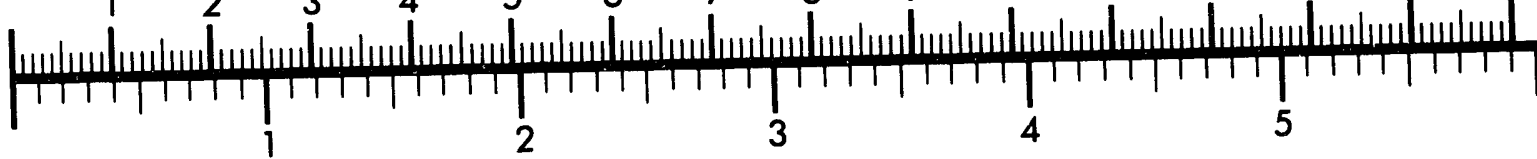

1100 Wayne Avenue, Suite 1100 Silver Spring, Maryland 20910 $301 / 587-8202$ Inches

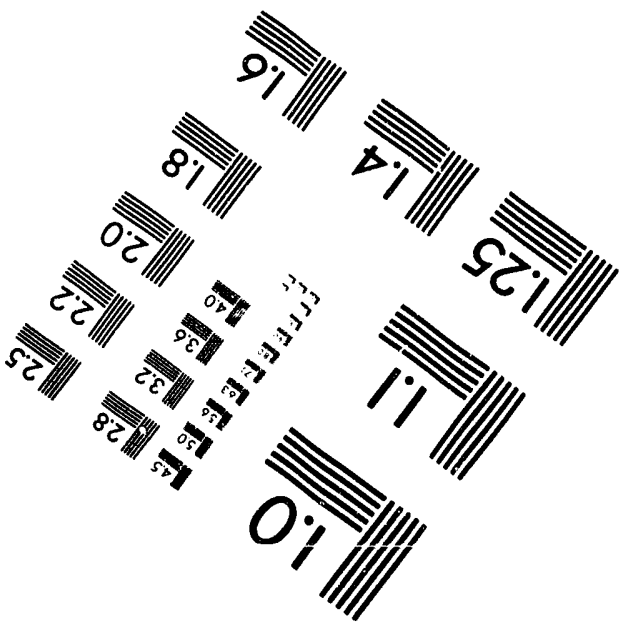

MANUFACTURED TO AIIM STANDARDS

BY APPLIED IMAGE. INC.

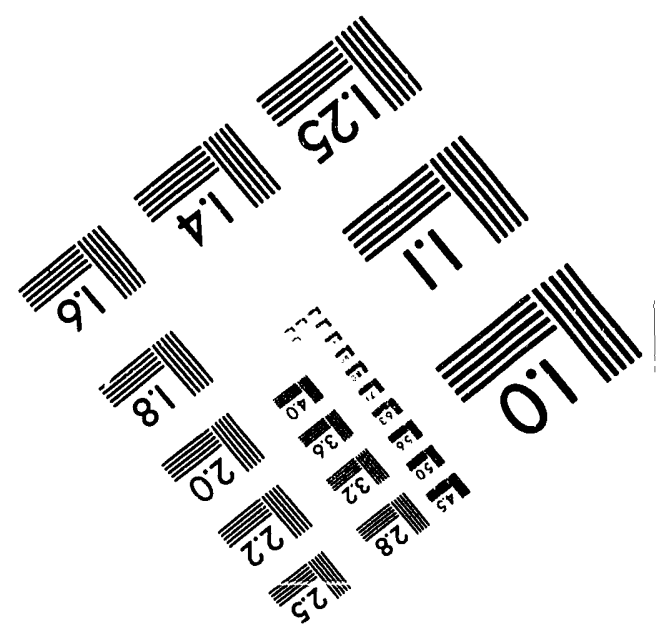



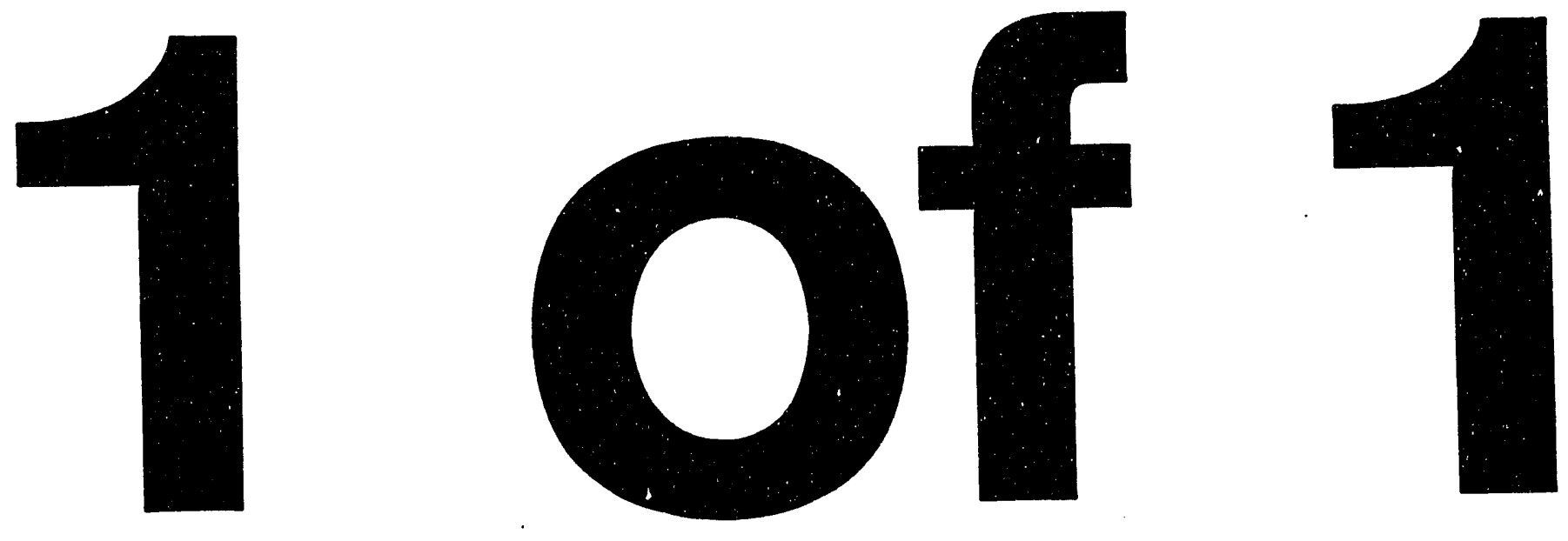


\title{
ANK/CMT/CP - 7980) \\ CONF- $930802-13$
}

\section{ADVANCED BATTERIES FOR ELECTRIC VEHICLE APPLICATIONS}

\author{
by
}

D. R. Vissers, W. H. DeLuca, and G. L. Henriksen

Argonne National Laboratory

Chemical Technology Division

9700 South Cass Avenue

Argonne, II 60439

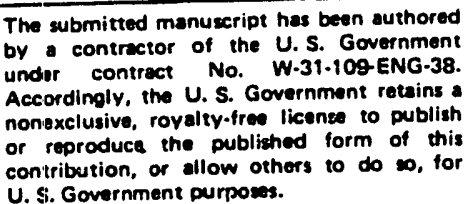

U. S. Government purposes.

To be published in the symposium proceedings of the American Chemical Society Meeting, Chicago, Illinois, August 22-27, 1993. 


\title{
ADVANCED BATTERIES FOR ELECTRIC VEHICLE APPLICATIONS
}

\author{
by
}

\author{
D. R. Vissers, W. H. Deluca, and G. L. Henriksen \\ Argonne National Laboratory \\ Electrochemical Technology Program \\ Chemical Technology Division \\ 9700 South Cass Avenue \\ Argonne, IL 60439
}

Keywords: Electric, Vehicles, Zero Emission Vehicles, Advanced Batteries

\subsection{INTRODUCTION}

In the late 1970s, the U.S. government launched major battery R\&D projects to assist industry in the development and commercialization of electric vehicles (EVs). These efforts were initiated to relieve U.S. dependence on foreign oil, following the 1973 oil crisis. The Electric \& Hybrid Vehicle Program was established under Public Law 94-413, entitled "Electric and Hybrid Vehicle Research, Development, and Demonstration Act of 1976." This program, residing within the Energy Research and Development Administration--the precursor to the U.S. Department of Energy (DOE)--was responsible for establishing and monitoring federally funded EV projects, including the EV battery R\&D projects. Also, the Electric Power Research Institute (EPRI), through its Electric Transportation Program, helped support advanced battery R\&D projects for EVs. However, funding for these projects was not sustained at a sufficient level through the 1980 s to significantly advance any of the battery technologies being supported by DOE and/or EPRI.

In the early 1990s, concern over deteriorating air quality in many urban areas of the U.S. caused state legislatures to begin mandating the introduction of zero emission vehicles (ZEVs), ultra-low emission vehicles, and low emission vehicles. In 1990, California was the first state to enact such legislation for the Los Angeles Basin area of southem California. According to the current definition, battery-powered or flywheel-powered vehicles are the only types of vehicles that qualify as ZEVs. Califomia requires automobile manufacturers to market ZEVs at the rate of $2 \%$ in 1998 and $10 \%$ in 2003 . Several states along the East coast are enacting similar legislation. Maine, Maryland, New Jersey, and New York are in various stages of enacting legislation, while surrounding states are considering it.

In January 1991, Chrysler, Ford, and General Motors formed a partnership, named the U.S. Advanced Battery Consortium (USABC), to accelerate the development and commercialization of selected advanced-battery technologies. Both EPRI and DOE joined with the U.S. auto industry to make it a joint government/industry consortium later that same year. According to existing agreements, which run through 1995, DOE provides 50\% of the funds and industry provides the other $50 \%$. Total funding for these projects could reach $\$ 260$ million during this time frame.

Also, a number of international battery companies formed a consortium in 1992, the Advanced Lead-Acid Battery Consortium (ALABC), to promote the development of advanced lead-acid batteries for EV and hybrid vehicle (HV) applications. This was done in response to a decision by the USABC to fund R\&D only on more-advanced battery technologies. The ALABC research efforts are directed at increasing cycle life, achieving rapid recharge capabilities, and increasing specific energy of lead-acid batteries. It is a 38-member 11-nation consortium.

Finally, in October 1992 former President Bush signed into law the Energy Policy Act of 1992, which includes many new initiatives relating to EVs. Included in these initiatives are: 
o Major multi-year (1993-8) R\&D programs on batteries and EVs

- A 10-year $\$ 50$ million EV demonstration program

- A 5-year $\$ 40$ million infrastructure development program

- A $\$ 50$ million program to assist states in developing and implementing incentives

- A federal tax incentive program

\subsection{REQUIREMENTS}

The requirements for an EV battery can vary significantly, depending on the type of vehicle and its intended mission. When the USABC established criteria for advanced battery technologies, they necessarily avoided this issue and created two sets of generic goals: one for mid-term batteries and the other (more demanding) for longterm batteries. The USABC primary battery criteria for mid-term and long-term batteries are provided in Table 1 .

Table 1. USABC Primary Battery Criteria for Mid-Term and Long-Term Batteries.

\begin{tabular}{|c|c|c|}
\hline 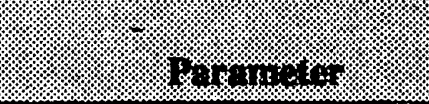 & 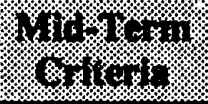 & 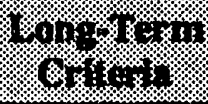 \\
\hline Specific Energy (Wh/kg) & 100 & 200 \\
\hline Specific Power (W/kg)* & 200 & 400 \\
\hline Energy Density $(\mathrm{Wh} / \mathrm{L})$ & 150 & 300 \\
\hline Power Density (W/L)* & 300 & 600 \\
\hline Cycle Life (cycles) & 600 & 1000 \\
\hline Calendar Life (years) & 5 & 10 \\
\hline Recharge Time (hours) & 6 & $3-6$ \\
\hline Selling Price $(\$ / \mathbf{k W h})$ & 150 & 100 \\
\hline
\end{tabular}

*30-second peak power @ 80\% depth of discharge (DOD)

Additional criteria related to electrochemical efficiency, thermal efficiency, abuse tolerance, and freedom from maintenance were established by the USABC. Again these are generic criteria not tied to specific vehicles or vehicle missions.

It is possible to use published information on electric vehicles under development today to establish some vehiclerelated requirements for EV batteries. These requirements are based on battery technologies available today or in the near term and would likely be altered by the availability of a more-advanced battery system. A few of these requirements are provided in Table 2.

As shown in Table 2, the power-to-energy ratio of the batteries for these two vehicle applications differ significantly. This is because the electric van acceleration is intended to be comparable to that of a diesel-powered van, while the acceleration of the passenger vehicle is intended to be comparable to that of a sports car. Another difference between the van and passenger vehicle applications is the importance placed on the space occupied by the battery. On a relative basis, more space is available in a van and, therefore, battery weight becomes the controlling parameter. However, in passenger vehicle applications, it is more difficult to allocate space for the battery, and battery volume becomes a more significant parameter. 
Table 2. Vehicle Related Battery Requirements.

\begin{tabular}{|c|c|c|}
\hline i. & murin. & 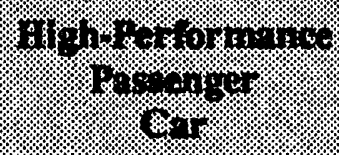 \\
\hline Energy (kWh) & 40 & 14 \\
\hline Power $(\mathrm{kW})$ & 60 & 85 \\
\hline Weight (kg) & 650 & 410 \\
\hline Size $(\mathrm{LxWxH}$, in $\mathrm{cm})$ & $191 \times 79 \times 25$ & $205 \times 20 \times 33$ \\
\hline $\begin{array}{c}\text { Voltage (V) } \\
\text { Maximum } \\
\text { Minimum }\end{array}$ & $\begin{array}{l}260 \\
140\end{array}$ & $\begin{array}{l}415 \\
320\end{array}$ \\
\hline Max Current (A) & 340 & 340 \\
\hline Power/Energy Ratio & 1.5 & 6.1 \\
\hline
\end{tabular}

\subsection{TECHNOLOGIES}

With the advent of requirements for zero emission vehicles in Califomia, the U.S. government and the U.S. automobile manufacturers have launched a concerted effort to develop advanced batteries for electric vehicles. In this overview of the battery technologies, we will review the major existing or near-term systems, as well as the advanced systems being developed for EV applications. It is important to note that this overview does not cover all of the advanced batteries being developed in the world today.

\subsection{Near-Term Batteries}

By definition, near-term batteries are currently being manufactured commercially arid are available for use in electric vehicles in large volumes. These batteries include the nickel/cadmium and lead-acid batteries. Both battery types have their advantages and disadvantages.

For example, the lead-acid battery dominates the SLI market in the United States for automobiles and trucks. It is quite inexpensive and has excellent power characteristics. However, as a propulsion device for an electric vehicle, specific energy is quite low, limiting the vehicle range to about 60 to 100 miles. Nevertheless, the first generation of commercial electric vehicles will probably utilize these batteries because of their widespread availability and low cost.

The nickel/cadmium battery also possesses excellent power but has significantly better specific energy and longer cycle life than the lead-acid system. However, it is very expensive and, because of its use of cadmium, raises environmental concerns related to disposal of spent batteries. This system, however, may ivell be used in a limited number of first generation EVs because of its performance and life characteristics.

\subsection{Advanced Batteries}

The advanced batteries are divided into mid-term (available in 5 years) and long-term (available in 5 to 10 years) systems. The mid-term batteries include sodium/sulfur, sodium/nickel chloride, nickel/metal hydride, zinc/air, 
zinc/bromine, and nickel/iron systems. The long-term batteries principally include the lithium-polymer and the lithium/iron disulfide systems; the latter could also be available in the mid term.

\subsubsection{Mid-Term Batteries}

Of the mid-term batteries, the sodium/sulfur and sodium/nickel chloride systems offer the highest specific energies. Sodium/sulfur offers higher power, while the sodium/nickel chloride offers longer life. On the other hand, the nickel/metal hydride system offers the best power and may approach the sodium-based batteries in specific energy. The zinc/air and zinc/bromine batteries have energies similar to those of the sodium-based batteries but are limited in power. Finally, the nickel/iron systin has specific energies comparable to those of nickel/cadmium, but lacks the power of the nickel/cadmium system and tends to exhibit poor columbic efficiency because of the excessive amount of hydrogen that is generated on charge.

\subsubsection{Long-Term Batteries}

The long-term batteries are expected to have very high specific energy (200 Wh/kg) and specific power (400 W/kg) with calendar lifes of 10 years. The lithium/iron disulfide system appears to be further advanced than the lithium-polymer system at present, but because of the proprietary nature of the development efforts, on the latter, it is difficult to assess its status and exact degree of development. Both of these systems appear very promising, and significant efforts on their development are being carried out in the United States.

It is important to note that the lithium-polymer system operates at about $60-120^{\circ} \mathrm{C}$, while the lithium/iron disulfide system operates at slightly over $400^{\circ} \mathrm{C}$. Attaining the $400 \mathrm{~W} / \mathrm{kg}$ specific power will be a technical challenge for any battery system, more so for the low temperature systems.

\subsection{PERFORMANCE AND LIFE TESTING AT ANL}

Advanced-battery technology evaluations are performed under simulated electric-vehicle operating conditions at ANL's Analysis \& Diagnostic Laboratory (ADL). In this segment of the paper we briefly review the performance and cycle-life test results obtained at ANL on several near-term and mid-term battery technologies. The tests were conducted over a period of several years--mainly during the period of 1990 thru 1992--for DOE's Electric and Hybrid Propulsion Division and EPRI's Electric Transportation Program. The tests were conducted on a wide range of hardware, covering single cells to multi-cell modules, encompassing six types of battery technologies-$\mathrm{Na} / \mathrm{S}, \mathrm{Zn} / \mathrm{Br}_{2}, \mathrm{Ni} / \mathrm{MH}, \mathrm{Ni} / \mathrm{Cd}, \mathrm{Ni} / \mathrm{Fe}$, and $\mathrm{Pb}$-Acid.

Table 3 lists the general specifications and best performance demonstrated by each EV battery technology. Plots of specific energy and specific peak power for each technology are given in Figs. 1 and 2, respectively. The specific energies were measured using constant power discharges to $100 \%$ depth of discharge (DOD). The specific peak powers were derived from driving profile discharge data and are plotted as a function of DOD, based on available energy for the average power discharge rate.

\subsection{Sodium/Sulfur System}

An 8-V Na/S module from Chloride Silent Power Ltd. (CSPL) was under test from June 1990 to March 1992. The module contained 120 cells (10-Ah each) configured into 30 parallel-connected striigs of four series-connected cells. This 300 -Ah module was of the same design and assembly as those (24 series-connected modules) in the battery system developed for the Ford ETX-Il vehicle (a light-duty van based on the Ford Aerostar). Life testing with Simplified Federal Urban Driving Schedule (SFUDS) discharges to a DOD of $100 \%$ was started in October 1990 , after completion of the performance characterization tests $(-120$ cycles accrued). Test results indicated that the specific energy of this module is similar to that of the ASEA Brown Boveri (ABB) battery previously tested at ANL (see Table 3). However, the CSPL module had a higher internal resistance and, therefore, could not 
achieve as high a peak power. End-of-life ( $<80 \%$ of initial SFUDS discharge energy) occurred at cycle 795 , but testing was continued to acquire additional statistics for cell failure analyses. Testing was halted in March 1992 (21 months and 973 cycles at operating temperature) when the SFUDS discharge energy decreased to $<75 \%$ of its initial level. There was a significant drop in module capacity between $\mathbf{4 5 0}$ and 550 cycles of operation, which reflected the loss of four 4-cell strings ( -40 -Ah loss). Module resistance increased by $-20 \%$, which also indicated the loss of four strings in the 30-string battery. Owing to the increase in module resistance with life, the peak power declined from an initial $94 \mathrm{~W} / \mathrm{kg}$ to only $68 \mathrm{~W} / \mathrm{kg}$ at the end of testing (50\% DOD). After 973 cycles, the module retained $-79 \%$ of its initial 292 -Ah capacity (3-h rate) and $-73 \%$ of its initial 2084 -Wh SFUDS discharge energy (100\% DOD). The Na/S technology approaches the USABC mid-term goals.

Table 3. Performance Summary of EV Battery Systems Evaluated in the ADL Between January 1991 and December 1992

\begin{tabular}{|c|c|c|c|c|c|c|c|c|c|c|c|}
\hline \multicolumn{3}{|c|}{ Buteary Dascription } & \multicolumn{2}{|c|}{ Initial Module } & \multirow[b]{2}{*}{$\begin{array}{l}\text { Specific } \\
\text { Enerey. } \\
\text { Whas }\end{array}$} & \multirow[b]{2}{*}{$\begin{array}{l}\text { Enery } \\
\text { Deneity, } \\
\text { Wha }\end{array}$} & \multirow[b]{2}{*}{$\begin{array}{l}\text { Pant } \\
\text { Power, } \\
\text { Whes }\end{array}$} & \multicolumn{2}{|c|}{ Ediciency" } & \multirow[b]{2}{*}{$\begin{array}{l}\text { ura" } \\
\text { syclas }\end{array}$} & \multirow[b]{2}{*}{$\begin{array}{c}\text { Vm } \\
\text { Range, } \\
\text { mi (m) }\end{array}$} \\
\hline Technoloey & Manufecture & Model & $\begin{array}{c}\text { Weight } \\
\text { ky }\end{array}$ & $\begin{array}{c}\text { Capecity: } \\
\text { Ah }\end{array}$ & & & & $\begin{array}{c}\text { Coulantia } \\
\&\end{array}$ & $\ln _{x}$ & & \\
\hline $\begin{array}{l}\text { Sodium/ } \\
\text { Sulfur }\end{array}$ & $\begin{array}{l}\text { ABB } \\
\text { CSPL }\end{array}$ & $\begin{array}{l}\text { B.11" } \\
\text { BP.MK3 } \\
\end{array}$ & $\begin{array}{l}233 \\
29.2\end{array}$ & $\begin{array}{l}238 \\
292 \\
\end{array}$ & $\begin{array}{l}81 \\
79^{4}\end{array}$ & $\begin{array}{c}83 \\
123^{\prime}\end{array}$ & $\begin{array}{l}152 \\
90^{\prime}\end{array}$ & $\begin{array}{l}100 \\
100 \\
\end{array}$ & $\begin{array}{l}91 \\
8 \\
\end{array}$ & $\begin{array}{l}592 \\
795\end{array}$ & $\begin{array}{l}154(246) \\
150(240)\end{array}$ \\
\hline $\begin{array}{l}\text { Zinc/ } \\
\text { Bromine }\end{array}$ & SEA & $\begin{array}{l}2 B B \\
5 / 48\end{array}$ & 81 & 126 & 79 & 56 & 40 & 93 & 75 & 334 & 93 (149) \\
\hline $\begin{array}{l}\text { Nickel/Metal } \\
\text { Hyctride }\end{array}$ & Ovonics & H.Cell & 0.628 & 28.0 & s5 & 152 & 175 & 90 & 80 & sose & 97 (15s) \\
\hline $\begin{array}{l}\text { Nickel/ } \\
\text { Cadmium }\end{array}$ & SAFT & $\begin{array}{l}\text { STMS. } \\
200\end{array}$ & 24.5 & 214 & 35 & 104 & 175 & 90 & 78 & $1018^{b}$ & $102(163)$ \\
\hline Nickel/Iron & Engle.Picher & NIF200 & 25 & 203 & 51 & 118 & 99 & 74 & 58 & 918ed & 87 (139) \\
\hline Lead-Acid & $\begin{array}{l}\text { Sonnenschein } \\
\text { CEVS }\end{array}$ & $\begin{array}{l}6 V 160 \\
3 E T 205\end{array}$ & $\begin{array}{l}31.5 \\
32.8 \\
\end{array}$ & $\begin{array}{l}184 \\
185\end{array}$ & $\begin{array}{l}36 \\
33 \\
\end{array}$ & $\begin{array}{l}92 \\
78 \\
\end{array}$ & $\begin{array}{l}91 \\
68 \\
\end{array}$ & $\begin{array}{l}94 \\
87\end{array}$ & $\begin{array}{l}84 \\
68 \\
\end{array}$ & $\begin{array}{l}370^{m} \\
149 \\
\end{array}$ & $\begin{array}{ll}51 & (12) \\
47 & (75) \\
\end{array}$ \\
\hline \multicolumn{12}{|c|}{ 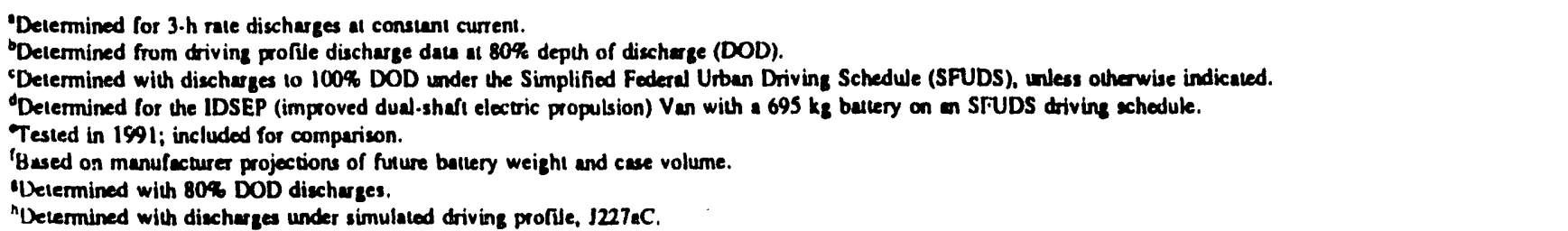 } \\
\hline
\end{tabular}

\subsection{Zinc/Bromine System}

A 5-kWh, 48-V Zn/Br module (ZBB-5/48) from the Studiengesellschaft fur Energiespeicher und Antriebssysteme (SEA) (Research Group for Energy Storage and Propulsion Systems, Austria) underwent EV performance and life testing from November 1989 to June 1991. Performance characterization tests showed that the SEA battery has good specific energy ( $-79 \mathrm{Wh} / \mathrm{kg}$ at 3-h rate) but low power capability ( $-53 \mathrm{~W} / \mathrm{kg}$ at $50 \% \mathrm{DOD})$. The low power is due to a high internal battery resistance. The battery also exhibited a high self-discharge loss $(-20 \%$ loss in $24 \mathrm{~h}$ ) when its electrolyte pumping motors remain energized. This loss is significantly reduced when pump operation is halted during extended open-circuit times. Life testing with SFUDS discharges to 100\% DOD was started in March 1990 after performance testing ( $\approx 130$ cycles accrued). Because of the high module resistance, a peak discharge current limit (150 A) had to be imposed with SFUDS discharges to avoid reaching the discharge cut-off voltage (DCOV) on the first $79 \mathrm{~W} / \mathrm{kg}$ power peak. With a $150 \mathrm{~A}$ current limit, a maximum power of $\sim 67$ W/kg was obtained at the start of the discharge, and $50 \mathrm{~W} / \mathrm{kg}$ was attained at the $27-\mathrm{V} \mathrm{DCOV}$. The module reached end-of-life ( $>20 \%$ loss of initial capacity) after 334 cycles. The power characteristics of this technology need to be significantly enhanced if it is to be used for EV applications. 

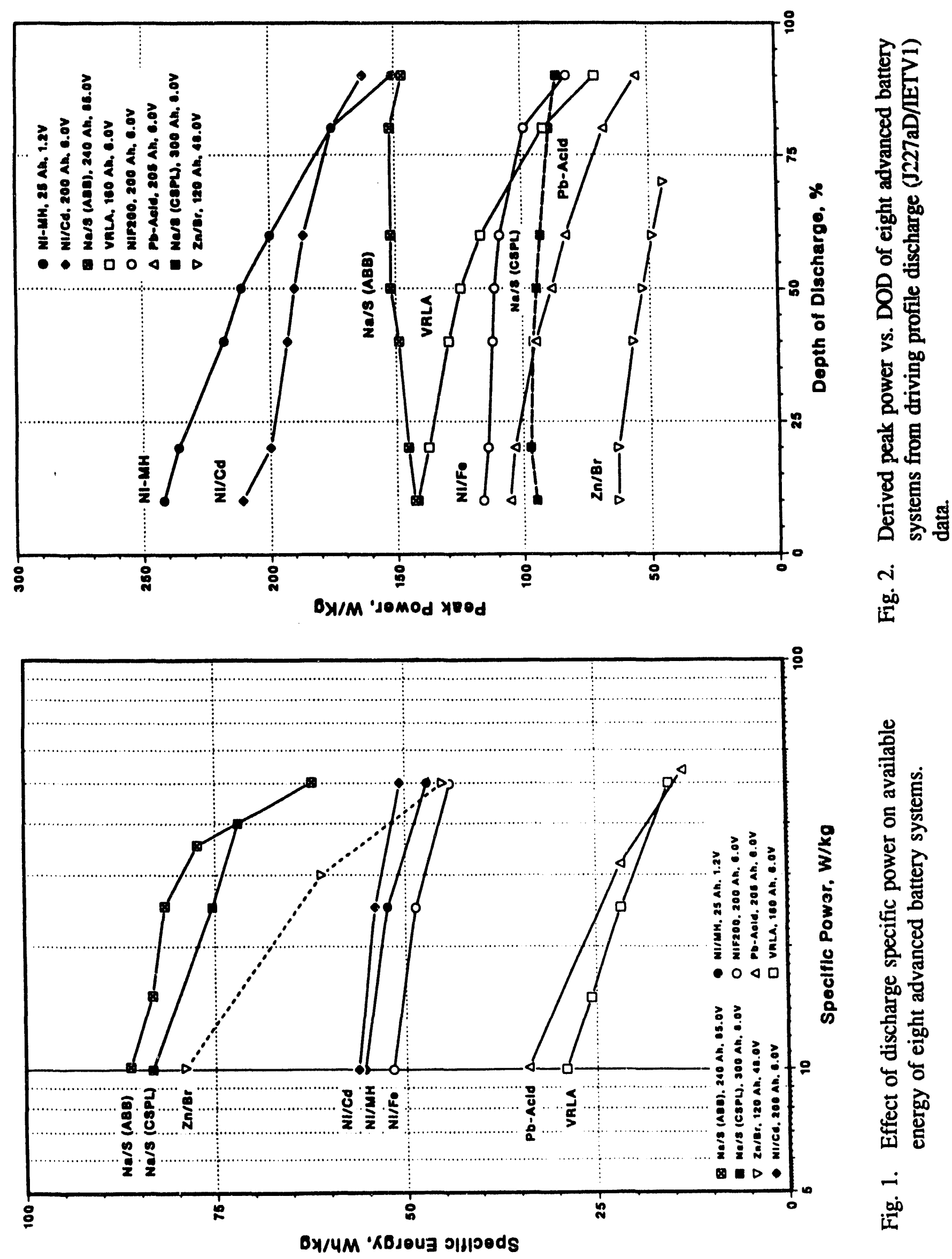


\subsection{Nickel/Metal Hydride (Ni/MH) System}

Performance and life tests were conducted on two Ni/MH cells (25-Ah rating) manufactured by Ovonics Battery Co. (Troy, MI) to determine the suitability of this technology for EV applications. The two cells were delivered to ANL in June 1991. Performance characterization tests were completed, and life evaluation (SFUDS discharges to 80\% DOD) started in November 1991. The peak power of the H-cells is the highest measured at the ADL to date (175 W/kg at $80 \% \mathrm{DOD}$ and $-200 \mathrm{~W} / \mathrm{kg}$ at $50 \% \mathrm{DOD})$. A high peak power provides full capacity and maximal vehicle range for all driving profile discharges. One H-cell was removed froin life test after 380 cycles due to a sudden decline in capacity (to $<70 \%$ of its initial 25 -Ah capacity) caused by electrolyte loss. Water $(13.6 \mathrm{~g})$ was added to this valve-regulated cell, and full capacity $(26.5 \mathrm{Ah})$ was achieved on a subsequent discharge. Thereafter, the capacity declined at a rate of $-0.5 \mathrm{Ah} /$ cycle. Testing was halted when the capacity declined to $13.8 \mathrm{Ah}$ on cycle 399 . Cell weight was reduced again $(6.3 \mathrm{~g})$. The problem was later found to be caused by a faulty pressure release vent.

The second H-cell was removed from life test after 533 cycles due to capacity and power loss. End-of-life (EOL) with SFUDS discharges to 80\% DOD occurred on cycle 505. The weight of this cell did nut change significantly with life. The charge retum was increased from $120 \%$ to $150 \%$ after EOL, but no improvement in cell capacity resulted. The cell retained $-78 \%$ of its initial 28 -Ah capacity (3-h rate) when testing was halted. Both H-cells were returned to Ovonics for further analyses. This battery technology has excellent potential to meet the USABC mid-term performance goals.

\subsection{Nickel/Cadmium System}

Life tests were conducted on a 6-V Ni/Cd module (190-Ah rating) manufactured by SAFT (Industrial Storage Battery Division), France, from April 1990 to August 1992. The module was received from Idaho National Engineering Laboratory, where it had completed 35 performance characterization cycles. Life testing was started at the $\mathrm{ADL}$ in June 1990 after 78 cycles of performance testing. Life evaluation was conducted with discharges to $100 \%$ DOD using the J227aC driving profile for a Chrysler TEVan. The module had completed 1018 cycles and still retained $-99 \%$ of its initial capacity (3-h rate) when it was voluntarily removed from test. At that time, the TEVan discharge energy had only declined to $-96 \%$ of its initial value. Variations in module resistance, IRfree voltage, and peak power vs. DOD during the life evaluation were examined. Analyses showed that module resistance had increased by $-23 \%$, and $\mathbb{R}$-free voltage had remained constant to within $1.0 \%$. As a result of the increased module resistance, the peak power was decreased from 190 to $154 \mathrm{~W} / \mathrm{kg}$ at $50 \%$ DOD ( $19 \%$ decrease) between cycles 46 and 1016. This module was sent to EPRI for other EV evaluations. The Ni/Cd battery technology has performance very comparable to the Ni/MH battery technology.

\subsection{Advanced Nickel//ron System}

Life tests were conducted on four advanced Ni/Fe modules (NIF200) from Eagle-Picher Industries, Inc. The NIF200 design provides a capacity of $200 \mathrm{Ah}$ in the same module package as the 170-Ah module developed for the dual-shaft electric propulsion (DSEP) vehicle developed by Eaton Corp. The longest operating module completed 918 cycles with discharges to $80 \%$ DOD (J227aC driving profile for G-Van) before reaching EOL in April 1992. Another module was cycled using an ANL-recommended charge regime from November 1991 to October 1992. The module completed 394 cycles (to 100\% DOD using J227aC for a Chrysler TEVan) before reaching EOL. Module life was less than expected based on that exhibited by early NIF 200 modules. The two remaining NIF200 modules were voluntarily removed from testing to prepare for future deliverables. This technology with its excellent cycle life and moderate power could be used as a near-term battery for EVs. 


\subsection{Recombinant Lead-Acid Systems}

Tests were started in December 1989 for EPRI on two 6-V, valve-regulated lead-acid (VRLA) modules with a gelled electrolyte manufactured by Sonnenschein Battery Co. (Germany). The maintenance-free cells were equipped with pressure-relief valves for gas venting and used an antimony-free alloy. Both modules completed performance characterization, and one underwent life testing with J227aC/G-Van discharges to 100\% DOD. After 370 cycles, the energy obtained on simulated driving profile discharges had declined to $80 \%$ of its initial level. New modules were delivered from Sonnenschein, and one was placed on ute test using G-Van discharges. The module was operated to 100\% DOD for 122 cycles and then changed to 80\% DOD cycling. This module completed 448 cycles before reaching end-of-life (100\% DOD condition reached before the 80\% DOD energy obtained). At that time, the 3-h rate capacity had only declined by $=9 \%$. This lead-acid battery technology appears very promising and will probably be used in near-term EVs.

\subsection{Tubular Lead-Acid System}

Two advanced, three-cell, lead-acid modules with tubular positive electrodes (3ET205) made by Chloride EV Systems Ltd. (CEVS), England, were acquired and tested in January 1991. This test measured the 3ET205 cycle life with SFUDS discharges (100\% DOD) for comparison with that achieved in an EPRI-sponsored test using $\mathrm{J} 227 \mathrm{aC} / \mathrm{G}-\mathrm{Van}$ discharges to $100 \%$ DOD. Both of the new modules underwent an abbreviated performance characterization, and one was selected for life testing with SFUDS discharges. After 149 cycles, this module reached end-of-life ( $<80 \%$ of initial energy). In the EPRI test (1990), the 3ET205 module completed 715 cycles before reaching end-of-life. Post-test analyses revealed that both modules failed due to deterioration of the negative electrodes, caused by high levels of antimony and by poor adhesion between the active materials and the grids. The antimony was generated by corrosion of the positive grids and plated onto the negative electrodes during operation. Charging efficiency and effective capacity of the electrodes were consequently reduced. The cells in the module using SFUDS discharges had a greater divergence in post-test findings than those observed in the EPRI module. Hence, cell mismatch may have impaired the evaluation of the SFUDS test. This particular lead-acid battery exhibited limited cycle life.

\subsection{CONCLUSIONS}

It will be very difficult for any one battery system to meet the propulsion requirements of the different vehicle configurations. For example, while van applications allow significant space for battery systems and require only a power-to-energy ratio of 1 or 2 , batteries used in high-performance passenger cars or hybrid vehicles will require power-to-energy ratios of 6 or 7 and will allow only a minimal space for the battery system. Thus, a battery such as a lead-acid system may be very suitable for a van application but might be entirely inappropriate for a commuter or hybrid vehicle, where much higher power and energy densities are required. Certainly, some of the advanced batteries, such as the lithium/iron disulfide system, when they are developed, could be configured for different vehicle configurations. That is, an advanced battery with a power-to-energy ratio of 6 or 7 might be designed for a hybrid vehicle, while this same battery might be redesigned for a van with a power-to-energy ratio of 2 .

The development of advanced batteries for electric vehicles is going to require many years and many millions of dollars before they are ready for commercial EV applications. While the DOE/USABC initiative will certainly move battery technologies forward from their present levels, it is highly unlikely that this initiative will be successful in developing all the technologies to the point where they meet most of the battery requirements. Certainly, some of the technologies, such as lead-acid and nickel/cadmium, are near commercialization, but others, such as lithium-polymer and lithium/iron disulfide, require significantly more development before they will be commercial. Others, such as nickel/metal hydride, sodium/nickel chloride, and sodium/sulfur are at an intermediate stage of development. 
Table 4 provides a comparison of relative characteristics for near-term, mid-term, and long-term battery technologies. The performance and life data for $\mathrm{Pb}$-Acid, $\mathrm{Ni} / \mathrm{Cd}, \mathrm{Ni} / \mathrm{Fe}, \mathrm{Ni} / \mathrm{MH}, \mathrm{Zn} / \mathrm{Br}_{2}$, and $\mathrm{Na} / \mathrm{S}$ batteries are based on ANL's test data. Those for $\mathrm{Na} / \mathrm{NiCl}_{2}, \mathrm{Zn} / \mathrm{Air}, \mathrm{Li} / \mathrm{FeS}$, and $\mathrm{Li}$-polymer are based on developers' data and/or ANL projections scaled from cell data. Relative costs are ANL judgemerts based on our knowledge of materials' and processing costs for these techrologies. The information presented in Table 4 clearly illustrates a trend toward higher performance in moving from near-term to long-term batteries. However, there is a corsesponding increase in R\&D time and cost, along with a higher degree of uncertainty regarding the ultimate commercialization of these technologies for EV applications. Also, it appears that no battery technology is the ideal battery for every EV application. Some technologies combine high specific energy with low-to-moderate cost, but have peak power limitations. Others offer high specific energy and peak power, but appear to be more expensive. Therefore, a number of these technologies are likely to be used commercially as EV batteries to satisfy different EV vehicle market segments. Certainly, if the lithium/iron disulfide or the lithium-polymer batteries can achieve $200 \mathrm{Wh} / \mathrm{kg}$ and $400 \mathrm{~W} / \mathrm{kg}$, as specified by the USABC, an electric vehicle with an extended operating range $>200$ miles between recharges could be achievable.

Finally, it is important to understand that the development of viable electric vehicles will require many years of development and involve many iterations, both of the battery and of the vehicle itself. When one considers that this nation spends about $\mathbf{\$ 5 0}$ billion each year on imported oil, the bulk of which is utilized for transportation and the use of which significantly affects our urban environments, it is quite apparent that EVs, when developed, could have a tremendous beneficial effect on our environment and economy.

Table 4. Comparative Characteristics of Candidate Electric Vehicle Battery Systems

\begin{tabular}{|c|c|c|c|c|c|}
\hline (1) & 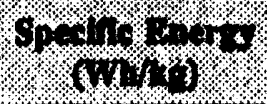 & 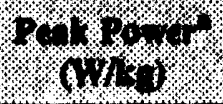 & 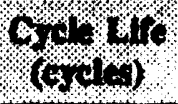 & Belintive 0.1 & 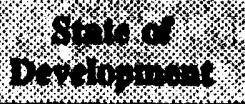 \\
\hline Lead-Acid & 25.40 & $70-90$ & $400-700$ & Low/Moderate & Commercial \\
\hline Nickel/Cadmium & 50.60 & 175 & $>1000$ & High & Commercial \\
\hline Nickel/Iron & $50-60$ & 100 & $>1000$ & Moderate/High & Prototype ${ }^{b}$ \\
\hline Nickel/Metal Hydride & $50-65$ & $170-300$ & -500 & Moderate/High & Module \\
\hline Zinc/Bromine & 80 & 40 & -300 & Low/Moderate & Prototype ${ }^{b}$ \\
\hline Sodium/Sulfur & 75.80 & $100-150$ & $800-900$ & Moderate & Protctype ${ }^{b}$ \\
\hline Sodium/Nickel Chloride & $80-100$ & $50-75$ & $>1000$ & Moderate/High & Prototype ${ }^{b}$ \\
\hline Zinc/Air & $75-100$ & -50 & $100-200$ & Low/Moderace & Prototype $^{b}$ \\
\hline Lithium/Iron Sulfide & $130-170$ & $200-500$ & TBD & Moderate & Stack \\
\hline Lithium-Polymer & $100-200$ & $100-300$ & TBD & Moderate/High & Cell \\
\hline
\end{tabular}

Peak power at $80 \%$ DOD for 30 seconds.

bFull-scale prototype EV batteries have been tested in vehicles.

\section{ACKNOWLEDGMENT}

This work was supported by the Department of Energy, Office of Transportation Systems, Electric and Hybrid Propulsion Division under Contract W-31-109-Eng-38, and the Electric Power Research Institute. 

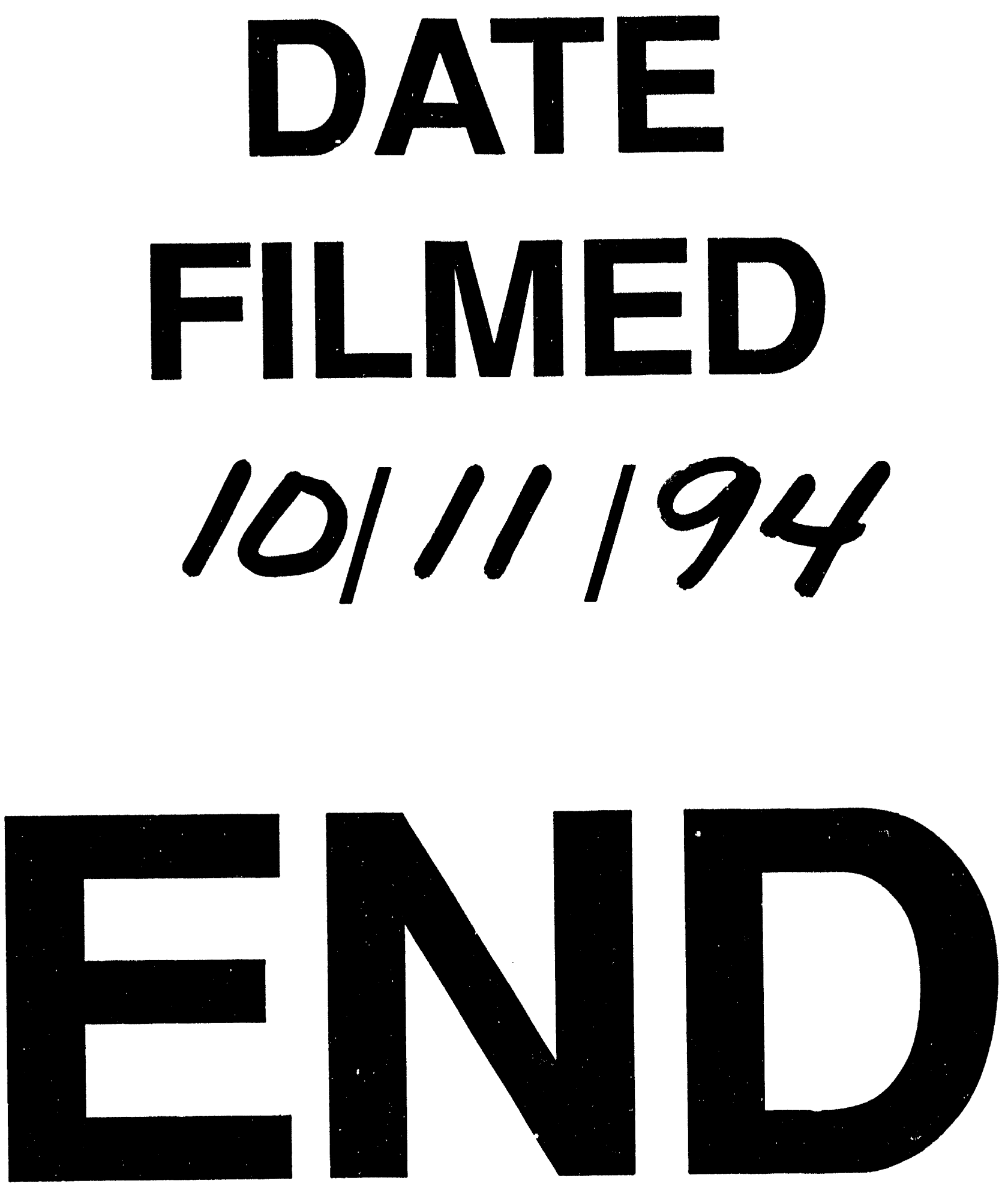